\title{
DISCUSSION
}

\section{LANGUAGE BORROWING: THEORY AND REALITY}

\author{
Pham Hung Viet*, Ly Toan Thang \\ Vietnam Institute of Lexicography and Encyclopedia, \\ 36 Hang Chuoi, Hai Ba Trung, Hanoi, Vietnam
}

Received 05 March 2017

Revised 16 May 2017; Accepted 18 May 2017

\begin{abstract}
The paper discusses the concept of language borrowing from different viewpoints and considers approaches to that linguistic phenomenon, from traditional to modern ones concerning borrowings at different levels in a language system, including phonetic, lexical and syntactic levels. These offer practical implications to research on the issue of borrowing in the Vietnamese language at present.
\end{abstract}

Keywords: language contact, language borrowing, loan words

\section{Introduction}

World-reputable linguists claim that languages and dialects do not exist in vacuum; rather, they often have contact with other languages and dialects. Such contact or exposure results in 'borrowed language' or language borrowing, which has long been a recurrent topic of discussions from various approaches by diferrent authors, particularly after the two classic works of Uriel Weinrich (1953) and Einar Haugen (1953).

In Vietnam, although there have been some studies on the phenomenon of borrowed words in Vietnamese from other languages such as Chinese, French, etc., like the works of Nguyen Tai Can, Phan Ngoc, Vuong Toan, amongst others, a number of aspects and issues remain untouched, even in the recent fairly elaborate theoretical work of Nguyen Van Khang (2007).

\footnotetext{
* Corresponding author. Tel.: 84-903257820

Email: vietpham1504@gmail.com
}

\section{The concepts of 'borrowing' / 'loans'}

As far as studies on the phenomenon of borrowing and loan words are concerned, the recent few decades have witnessed increasing focus on theoretical aspects with more comprehensive insights in comparison with the two classic works of Weinrich (1953) and Haugen (1953).

When researching borrowing phenomenon, most linguists tend to use the term 'borrowing' or 'loan' (Russian: Заимствование). In the particularly frequent field of lexical borrowing, the term 'loan word' or 'borrowed word' (Russian: заимствованное слово) sees the highest use in contrast with the term 'foreign word' (Russian: иностранное слово). Although these terms have become so popular for a long time, not a few scholars argue that they are not accurate because nothing is returned from the 'borrowing' language to the 'lending' language. In this line, several attempts have been made to suggest other terms so as to add higher accuracy to various 
aspects of 'borrowing' phenomenon, for example, importation, adoption, adaptation, integration, etc.

Despite differences in concepts and terminology, current researchers seem to prefer the definition of Thomason and Kaufman (1988:37) to the others 20 years earlier, which states, "Borrowing is a kind of blending or incorporation foreign features to the language of an indigenous group by the speakers of that language; although this native language was maintained, it experienced certain modifications due to those additional features". This definition is believed to be better than that of Haughen (1950: 212): “Borrowing is a 'reproduction' in one language of the patterns found earlier in another language".

Concerning the denotation and connotation of the concept of 'borrowing' as well as approaches to borrowing, recent decades witness the following major emerging trends:

(i) The first trend considers 'borrowing' in a broader context, in which 'borrowing' is just one type of crosslinguistic influences or of contactinduced change. Language contact includes many different phenomena such as borrowing, convergence and relexification. The most common 'products' of these phenomena are, inter alia, code-switching, pidgins, creoles, and mixed language.

(ii) The second trend considers 'borrowing' a 'multidisciplinary' issue, i.e. each discipline would approach borrowed words from a particular view such as linguistics, anthropology, sociology, psychology and ethnography. In linguistics, besides traditional fields which have long been interested in the phenomena of borrowing such as historical linguistics, comparative linguistics, therearenowinterdisciplinary research works such as socio-linguistics, psychological linguistics and 'cognitive linguistics'. However, the most notable emergence is 'contact linguistics'. With this new direction, the phenomenon of borrowing will be considered from a theory, from an approach that has many newer, broader and deeper features than traditional ones.

(iii) The third trend argues that traditional researchers rely more on diachronic linguistics and tend to investigate the development of language and language relations, the distinction between the borrowed and native characteristics in a particular language. However, later research pays more attention to the synchronic aspects of borrowing, focusing on the distinction between borrowing phenomena and other language phenomena such as 'interference', 'transference', 'convergence' and especially 'codeswitching'. There have been meticulous studies to find out the distinctive features between the two phenomena: borrowing and code-switching (see overview of Romaine 1995). Another noteworthy effort is in building lexical borrowing universals like the 'World Loanword Database' of 41 languages (Haspelmath \& Tadmor 2009).

(iv) The fourth trend agrees that research on borrowing phenomena does not merely deal with the results of borrowing, but it needs to be deepened from another perspective, which has not received adequate attention so far. It is the need to find out the answers to such questions as: What are the linguistic and non-linguistic processes underlying borrowing phenomena? How do these processes manage their functions? 
(v) The fifth trend supposes that traditional studies of borrowing phenomena have a tendency to explain language change due to internal factors. However, later research has shifted to external factors. The work which triggered this contactinduced change of a language is the book of the two authors Thomason and Kaufman (1988).

(vi) The influence of language contact can be 'reciprocal' / 'two-way' (mutual) or just 'one-way' (non-mutual). For example, Chinese exerted very profound influence on the development of Japanese, Korean, and Vietnamese, but the opposite seems negligible. When merely uni-directional, such influence is likely to give rise to 'linguistic hegemony' as evidenced in the languages of the ruling empires in their colonies like Latin, Chinese, Persian/Iranian, Portuguese, Spanish, English, French, etc.

(vii) Borrowing can leave profound and multifaceted impacts not only on the lexicon, but also on the phonology, morphology and syntax of the borrowing language. Such impacts may extend as deep as the 'organic layer' (stratum).

(viii) To establish a necessary distinction between the language that borrows (e.g. new words) and the language that lends (those words), it is important to use the following pairs of common terms:

+ Source language and Donor language

+ Recipient language and Target language

+ Borrowing language and Replica language

\section{Different approaches to the study of borrowing}

It is significant to note that borrowing phenomenon in general or loan words in particular should be approached from different views of various branches of linguistics as well as from interdisciplinary stance.

From traditional perspective of historical linguistics and comparative linguistics, there are three common issues of interest to study the phenomenon of borrowing: history of language, language relations and language change. For example, English loan words will be reviewed in the process of English language history, from Old English to Middle English and Modern English. In that process, English has borrowed from many prominent languages such as Latin, French and Norse (the language of the Vikings, Scandinave, which was believed to originate from Proto German). From the $9^{\text {th }}$ century onward, English borrowed many French and Norse words, the point of time considered to be the end of Old English and the beginning of Middle English.

From the perspective of sociolinguistics, studies of borrowing phenomena concentrate on influential factors which are socio-linguistic in nature (see Nguyen Van Khang 2007). It is worth noticing the notion of Weinrich, Herzgod and Labob (1968) on the so-called 'embedding problem' and 'constraints problem' related to social correlate. Some other issues are also noted, namely:

+ 'actuation problem' and 'transition problem', which refer to language characteristics: How do lending languages find way into borrowing languages? When do they change their functions?

+ 'evaluation problem' concerning the subjective evaluation of different researchers.

Also noteworthy is the notion of 'social status' of the lending and borrowing languages. 'Borrowing' typically reflects the social status of the relations between the two languages. Consequently, two terms emerged: 'Superstratum' is used for the language with higher social status and 'Substratum' for the language with lower social status. 
As mentioned above, with the emergence of subfields or the movement of 'contact linguistics' (see Winford 2003), borrowing phenomena are considered from an approach which has many new features. In the history of research on this phenomenon, the basic problems are discussed from language exposure perspective. Since the time of Uriel Weinrich (1953) and Einar Haugen (1953), for more than 60 years, there have been many different opinions on borrowing (see Thomason \& Kaufman 1988, Trask 2000, Van Coetsem 2000 Aikhenvald 2002, Heine and Kuteva 2005). Among them, more notable are the followings:

+ Borrowing is usually associated with situations of maintenance, whereas interference is often associated with acquiring a second language and language shift.

+ Borrowing is a type of characteristic transference from one language to another.

+ Borrowing is an incorporation of foreign features into the native language.

+ During the process of borrowing, some pairs of terms should be distinguished: 'importation' vs. 'substitution'; 'adoption' vs. 'adaptation'; 'adaptation' vs. 'integration'; 'adoption' vs. 'imitation'.

We can be more objective with the viewpoint of 'contact language' when it is estimated that approximately $60-70 \%$ of Vietnamese vocabulary were borrowed from Chinese in different historical periods. Similarly, when looking into English, in 1000 English words today, the average proportions are as follows (from Roberts, 1965):

- Pure English: 32\%

- Original French: 45\%

- Original Latin: 17\%

- Original German: 04\%

- From other languages (like Scandinave): 02\% and according to the general estimate of many scholars, the number of English loan words may be more, $60 \%-70 \%$ or $65 \%-75 \%$ !

\section{Borrowing at different linguistic levels}

Borrowing occurs not only at lexeme level (although it happens most popularly) but also from phoneme, morphology, syntax levels:

\subsection{Phonetics}

Languages usually borrow phonemes, phonemic distribution context, or phonetic rules from other languages. For example, in Latvian and Finnish, the first syllable stress was borrowed from Baltic region languages. Diffusion phenomena of phonetic change from [k] to [c] or from [ts] to [s] was borrowed from a number of languages.

\subsection{Morphology}

It is very interesting that English has borrowed affixes from many other languages. Studies by the Russian scholar Volodarskaya E. (2001) show the following results:

- Pure Anglo-Saxon: 11.7\%, including prefixes be-, for-, mid-, mis-, step-, twi-, un-, etc.

- Original French: 16\%, including prefixes counter, de-, demi-, en-, in-, inter, re-, sur-, etc.

- Original Latin: 45\%, including prefixes ante-, bi-, co-, dis-, extra-, micro-, multi-, non-, post-, pro-, semi-, sub-, super -, trans-, vice-, etc.

- Original Greek: 26.7\%, including prefixes $a-$, anti-, auto-, di-, hyper-, mono-, neo-, pan-, poly-, proto-, pseudo-, tri-, etc.

\subsection{Syntax}

It is obvious that the borrowing language was influenced by a certain structural model or a certain word order or one type of sentence structure of the lending language (for example subordinate clause is associated with the main clause by conjunction). It can be seen in various meticulous studies, for example, 'Grammatical Borrowing in Cross-Linguistic Perspective' by Matras and Sakel (2007). 


\section{Conclusion}

Borrowing is a common phenomenon across languages in the world, which occurs most frequently and apparently at lexical level. It also occurs at phonetic, morphological and syntactic levels to different degrees. It is important to understand the causes and impacts of language borrowing so as to properly treat borrowing in general and loan words, or 'foreign words' in particular. On the one hand, this will help preserve the purity of the national language, and on the other, make use of the positive impacts of borrowed linguistic features to enrich the national language.

\section{References}

\section{Foreign languages}

Aikhenvald A. (2002). Language Contact in Amazonia. Oxford University Press.

Haspelmath M. \& Tadmor U. (2009). Loanwords in the world languages: a comparative handbook. Berlin: Mouton de Gruyter.

Haugen E. (1950) "The analysis of linguistic borrowing”, Language, 26.

Haugen E. (1953) The Norwegian Language in America: A Study in Bilingual Behavior, Indiana University Press.

Heine B. and Kuteva T. (2005) Language Contact and Grammatical Change. Cambridge University Press.

Matras Y. and Sakel J. (2007) Grammatical Borrowing in Cross Linguistic Perspective. Mouton de Gruyter.

Romaine S. (1995) Bilingualism. $2^{\text {nd }}$ Ed. Blackwell.
Thomason S.G. \& Kaufman T. (1988) Language Contact, Creolization and Genetic Linguistics. University of California Press.

Trask R. L. (2000) The Dictionary of Historical and Comparative Linguistics. Edinburgh University Press.

Van Coetsem F. (2000) A General and Unified Theory of the Transmision Process in Language Contact. Heidelberg: Winter.

Volodarskaya E.F. (2001) "Zaimstovovanie kak universal'noe lingvisticheskoe yavlenie”. In Voprosy filologhii, No 1 (7), Moskva.

Weinrich U. (1953) Languages in Contact: Findings and Problems. Linguistic Circle of New York.

Weinrich U., Labov W. \& Herzgod M. I. (1968) "Empirical foundations for a theory of language change". In Lehman W.P. \& Malkiel (eds). Directions for historical linguistics. University of Texas Prees.

Winford D. (2003) An introduction to contact linguistics. Blackwell.

\section{Vietnamese}

Nguyễn Tài Cẩn (1979). Nguồn gốc và quá trình hình thành cách đọc Hán Việt (The origin and formation process of Sino-Vietnamese pronunciation). Nxb Khoa học xã hội.

Nguyễn Tài Cẩn (1979). Giáo trình lịch sủ ngũ âm tiếng Việt (so thảo) (Coursebook on Vietnamese historical phonetics (draft)). Nxb Giáo dục.

Nguyễn Văn Khang (2007). Tù ngoại lai trong tiếng Việt (Foreign words in Vietnamese). Nxb Giáo dục.

Phan Ngọc - Phạm Đức Dương (1983) Tiếp xúc ngôn ngũ ở Đông Nam Á (Language Contact in Southeast Asia). Viện Đông Nam Á.

Phan Ngọc (1992) Mẹo giải nghĩa tù Hán Việt (Tips for Sino-Vietnamese interpretation). Nxb Đà Nẵng.

Vương Toàn (1992) Tù gốc Pháp trong tiếng Việt (Vietnamese words from original French). Nxb Khoa học xã hội.

\title{
VỀ VẤN ĐỀ VAY MƯợN NGÔN NGỮ: LÍ THUYẾT VÀ THỰC TIỄN
}

\author{
Phạm Hùng Việt, Lý Toàn Thắng
}

Viện Tù điển học và Bách khoa thu Việt Nam, 36 Hàng Chuối, Hai Bà Trung, Hà Nội, Việt Nam

Tóm tắt: Bài báo thảo luận về khái niệm vay mượn ngôn ngữ theo nhiều quan điểm khác nhau, xem xét các cách tiếp cận đối với hiện tượng ngôn ngữ này từ truyền thống đến hiện đại ở nhiều cấp độ vay mượn trong hệ thống ngôn ngữ như ngữ âm, từ vựng và ngữ pháp. Điều này có ý nghĩa quan trọng đối với việc nghiên cứu vấn đề vay mượn trong tiếng Việt hiện nay.

Tù khóa: tiếp xúc ngôn ngữ, vay mượn ngôn ngữ, từ vay mượn 